\title{
Effects of School Location and Teachers' Quality on Students Performance in Business Studies Examination in Public Secondary Schools in Sapele Local Government Area of Delta State
}

\author{
Dr. (Mrs.) Ovwiroro Akpomudjere ${ }^{1}$ \\ ${ }^{1}$ College of Education, Warri, Delta State, Nigeria \\ Correspondence: Ovwiroro Akpomudjere, College of Education, Warri, Delta State, Nigeria. E-mail: \\ akpomujereovwiroro@yahoo.com
}

Received: May 15, 2019

Accepted: March 1, 2020

Online Published: March 24, 2020

doi:10.5539/hes.v10n2p114

URL: https://doi.org/10.5539/hes.v10n2p114

\begin{abstract}
The purpose of the study is to find out the effects of school location and teachers' quality on students performance in Business Studies Examination in public secondary schools in Sapele Local Government Area of Delta State Nigeria. Four research questions guided the study, and the expost facto research design was used for the study. The population of the study was 2579 students that sat for Business Studies in the Basic Education Certificate Examination in public secondary schools in Sapele Local Government Area of Delta State for 2016/2017 Academic Session. No sampling was done population was used as sample for the study, as well, no instrument was develop for data collection, data were collected on request from Ministry of Primary and Basic Education, Sapele Field Office. Data collected were analysed using simple frequency count and percentage for the research questions. The results show that location does not have significant effects on students' performance. Also, the findings revealed that qualification of teacher has significant effects on students' performance. Based on the findings of this study, it was concluded that school location does not have significant effects on students' performance in Business Studies examination in secondary schools in Delta State. As well, teachers' qualification has significant effects on students' performance in Business Studies examination in secondary schools in Delta State. Hence, it was recommended amongst others that Delta State Ministry of Basic and Secondary Education should employ qualified teachers to teach Business Studies in secondary schools in Delta State.
\end{abstract}

Keywords: teachers quality, school location, students' performance, business studies \& secondary schools

\section{Introduction}

Nigeria education pattern shifted from 6-3-3-4 to 9-3-4 system of education. According to Okolocha and Onyeneke (2013) Nigeria educational policy has been changing from one system to another in a bid to meeting local educational demands and international best practices in education. According to Federal Republic of Nigeria (FRN, 2008), the 9-3-4 comprises of six years of primary school categorised into lower basic (1-3) and middle basic (4-6); three years of junior secondary school (JSS 1-3) now called upper basic and three years of senior secondary school (SSS 1-3) and four years of tertiary education. According to FRN (2004), the goals of the national policy on education for secondary education which stipulated that secondary education is an instrument for national development that fosters the worth and development of the individual, for further education and development. The role of secondary education is to lay the foundation for further education.

As well, the broad aims of Secondary Education are to prepare students for useful living within the society and for higher education. Specifically, secondary education is to provide a higher level of education for all primary school leavers, offer diversified curricular to cater for all, provide sub-professional manpower in science, technology and commerce, provide technical knowledge and vocational skills, inspire desire for self-improvement and achievement and raise citizens who can think and respect the views of others (FRN, 2008). Udoukpong, Emah, and Umoren (2012) citing Inyang(1998) opined that, Business Studies is taught as one of the basic subjects that will enable students acquire further skills which are common and fundamental to all personal and occupational activities. According to Zailani (2015) Business Studies are an integral part of Vocational Education which encourages the use of the head and the hands in acquiring specific practical training required in 
business and industry at the junior secondary school level. Business studies are taught as integrated subjects such as book keeping, commerce, office practice, shorthand and typewriting. These subjects are offered by students in secondary schools at the junior and senior secondary level of education.

Akiri and Ugborugbo (2009) posited that the issue of poor academic performance of students in Nigeria has been of much concern to all and sundry. The problem is so much that it has led to the widely acclaimed fallen standard of education in Delta State and Nigeria at large. Okolocha and Onyeneke (2013) reported that the available records of some secondary schools visited revealed that, out of 1530 students that sat for business studies examination, only 699 got credit and above while others were either pass, failed or result withheld. As well, fieldwork carried out in selected Secondary Schools in Anambra State of Nigeria with respect to Nigeria Examination Council Organization (NECO), West African Senior School Certificate Examination (WASSCE) and Basic Education Certificate Examination (BECE) results revealed poor performance of students in Business subjects (Nwogu, 2011).

The academic achievement of a school child in any school subject can be attributed to many factors. According to Nwachukwu, (2004) the factors responsible for low achievement could be associated to socio-economic, gender, teacher, and school location. These factors as expressed by these researchers could contribute positively or negatively to the academic attainment of a school child. In fact, two of these factors are of interest in this study, that is, the school location and teacher quality.

Over time pupils' academic performance in both internal and external examinations had been used to determine excellence in teachers and teaching (Ajao 2001). Poor academic performance of students in Nigeria has been linked to poor teachers' performance in terms of accomplishing the teaching task, negative attitude to work and poor teaching habits which have been attributed to poor motivation (Ofoegbu 2004). According to Afe (2001), teachers have been shown to have an important influence on students' academic achievement and they also play a crucial role in educational attainment because the teacher is ultimately responsible for translating policy into action and principles based on practice during interaction with the students. According to Ewetan and Ewetan (2015), the issue of teacher as a factor that affects students academic performance has received a lot of attention in the literature and findings have been mixed and inconclusive, while some literature revealed that a number of teacher variables which include years of teaching experience, academic qualifications, teacher development programmes, availability of qualified teachers, teacher-student ratio, teacher attitude, degree of job satisfaction, motivation and salary affect students learning outcomes. Whereas, other literature found that these teacher variables had no significant influence on students' academic performance.

Akinfe, Olofinniyi and Fashiku (2012) reported that professionally qualified/trained teacher is an important teacher quality which enhanced students' academic performance. Similarly, Okoye, Momoh, Aigbomian, and Okecha (2008) study revealed that the teacher quality had positive significant relationship with performance in secondary schools in Delta State. Furthermore, Akpo (2012) reported that teacher educational qualifications have significant relationship with students' academic performance in junior secondary certificate Mathematics results in Namibia. However, Duze (2012) reported contrary view that teachers' qualification has no significant relationship to students' academic performance in public junior secondary schools (JSS) in Delta Central Senatorial District of Delta State.

Others believed that school location affects students' performance. The location of a school could be an urban or rural area. According to Funk and Wagnalls (1993) in Idialu (2013), urban areas are those thickly populated towns or cities with the basic amenities and facilities that make life comfortable, while rural areas are those places distinguished from towns and cities with little or no basic amenities or facilities. Nelson (2004) asserted that students from rural areas performed better than their urban counterparts in verbal aptitude, English language and total score using the National Common Entrance as a base. On the contrary, Reeves and Bylund (2005) do not see the relevance of school location whether urban or rural, to the academic achievement of students. They asserted that there is no clear evidence that rural school students are inferior to urban school students though there may always be differences in student academic achievement irrespective of where the school is sited. Similarly, Zappala (2002) in Idialu (2013) found out that location significantly influenced students' academic performance and there was significance difference in the performance of students from urban and rural schools in mathematics in Australia. As well, Idialu (2013) citing Onyeagu (2000) reported that, there is no locational influence on the performance of students.

It is against these backdrops that the researcher felt the need to conduct this research to find out the effects of school location and teachers' quality on students' performance in Business Studies Examination in public secondary schools in Sapele Local Government Area of Delta State Nigeria. 


\subsection{Statement of Problem}

The performance of students in Business Studies examination in public secondary schools in Delta State is worrisome, one may wonder why this is so. Some scholars believed that students from secondary schools in urban areas perform significantly better than their counterparts from secondary schools in rural areas because they felt that secondary schools in urban areas have quality human and material resources for the implementation of Business Studies curriculum. Hence, the need to conduct this study to find out the effects of school location and teachers' quality on students performance in Business Studies Examination in public secondary schools in Sapele Local Government Area of Delta State Nigeria.

\subsection{Significance of the Study}

This study will be significant to Federal and State Ministry of Education, school principals, Business Studies teachers, and future researchers. To the Federal and State Ministry of Education, the findings from the study will reveal the effects of teachers' quality and school location on students' performance in Business Studies examination in junior secondary schools. As well, the findings from the study will help school principals and Business Studies teachers to know the performance level of students in Business Studies based on teachers quality and school location. Furthermore, the findings of the study will help future researchers to draw inference when conducting related research.

\subsection{Purpose of the Study}

The purpose of the study is to find out the effects of school location and teachers' quality on students' performance in Business Studies Examination in public secondary schools in Sapele Local Government Area of Delta State Nigeria. Specifically, the study seeks to find out:

i. The performance of students from rural area in Business Studies Examination for 2016/2017 Academic Session in public secondary schools in Sapele Local Government Area of Delta State.

ii. The performance of students from urban area in Business Studies Examination for 2016/2017 Academic Session in public secondary schools in Sapele Local Government Area of Delta State.

iii. The performance of students in Business Studies Examination for 2016/2017 Academic Session in public secondary schools in Sapele Local Government Area of Delta State taught by teachers N.C.E.

iv. The performance of students in Business Studies Examination for 2016/2017 Academic Session in public secondary schools in Sapele Local Government Area of Delta State taught by teachers B.Sc Ed.

\subsection{Scope of the Study}

The study was conducted to ascertain the effects of school location and teachers' quality on students' performance in Business Studies Examination in public secondary schools in Sapele Local Government Area of Delta State.

\subsection{Research Questions}

The following research questions guided the study:

i. What is the performance of students from rural area in Business Studies Examination for 2016/2017 Academic Session in public secondary schools in Sapele Local Government Area of Delta State?

ii. What is the performance of students from urban area in Business Studies Examination for 2016/2017 Academic Session in public secondary schools in Sapele Local Government Area of Delta State?

iii. What is the performance of students in Business Studies Examination for 2016/2017 Academic Session in public secondary schools in Sapele Local Government Area of Delta State taught by teachers with N.C.E.?

iv. What is the performance of students in Business Studies Examination for 2016/2017 Academic Session in public secondary schools in Sapele Local Government Area of Delta State taught by teachers with B.Sc Ed.?

\section{Methods and Procedure}

Expost facto research design was adopted for the study. The population of the study was 2579 students that sat for Business Studies in the Basic Education Certificate Examination in public secondary schools in Sapele Local Government Area of Delta State for 2016/2017 Academic Session. No sampling was done population was used as sample for the study. No instrument was develop for data collection, rather the researcher wrote a letter to the Chief Inspector of Education, Ministry of Primary and Basic Education, Sapele Field Office to request for students' examination scores in Business Studies for 2016/2017 Academic Session, as well as the distribution of Business Studies teachers based on schools and qualification. Data collected were analysed using simple 
frequency count and percentage for the research questions.

\section{Results}

The results were presented based on the research questions:

Research Question 1: What is the performance of students from rural area in Business Studies Examination for 2016/2017 Academic Session in public secondary schools in Sapele Local Government Area of Delta State?

Table 1. Performance of students from rural area in Business Studies Examination for 2016/2017 Academic Session in public secondary schools in Sapele Local Government Area of Delta State

\begin{tabular}{|c|c|c|c|c|c|c|}
\hline $\mathbf{S} / \mathbf{N}$ & $\begin{array}{l}\text { Name } \\
\text { of Schools }\end{array}$ & $\begin{array}{l}\text { Number of } \\
\text { Students with } \\
\text { Excellent Grade }\end{array}$ & $\begin{array}{l}\text { Number of } \\
\text { Students with } \\
\text { Credit Grade }\end{array}$ & $\begin{array}{l}\text { Number of } \\
\text { Students with } \\
\text { Pass Grade }\end{array}$ & $\begin{array}{l}\text { Number of } \\
\text { Students with } \\
\text { Fail Grade }\end{array}$ & $\begin{array}{l}\text { Total } \\
\text { Numbers of } \\
\text { Students }\end{array}$ \\
\hline 1. & $\begin{array}{l}\text { Ogiedi } \\
\text { Mixed } \\
\text { Secondary } \\
\text { School }\end{array}$ & $44(40.37)$ & $34(31.19)$ & $16(14.68)$ & $\begin{array}{l}15 \\
(13.76)\end{array}$ & 109 \\
\hline 2. & $\begin{array}{l}\text { Ibada } \\
\text { Secondary } \\
\text { School }\end{array}$ & $\begin{array}{l}58 \\
(53.70)\end{array}$ & $\begin{array}{l}50 \\
(46.30)\end{array}$ & $\begin{array}{l}0 \\
(0.00)\end{array}$ & $\begin{array}{l}0 \\
(0.00)\end{array}$ & 108 \\
\hline 3. & $\begin{array}{l}\text { Adaka } \\
\text { Grammar } \\
\text { School }\end{array}$ & $\begin{array}{l}35 \\
(85.37)\end{array}$ & $\begin{array}{l}6 \\
(14.63)\end{array}$ & $\begin{array}{l}0 \\
(0.00)\end{array}$ & $\begin{array}{l}0 \\
(0.00)\end{array}$ & 41 \\
\hline 4. & $\begin{array}{l}\text { Ozue } \\
\text { Secondary } \\
\text { School }\end{array}$ & $\begin{array}{l}68 \\
(73.91)\end{array}$ & $\begin{array}{l}23 \\
(25.00)\end{array}$ & $\begin{array}{l}1 \\
(1.09)\end{array}$ & $\begin{array}{l}0 \\
(0.00)\end{array}$ & 92 \\
\hline 5. & $\begin{array}{l}\text { Elume } \\
\text { Grammar } \\
\text { School }\end{array}$ & $\begin{array}{l}34 \\
(64.15)\end{array}$ & $\begin{array}{l}19 \\
(35.85)\end{array}$ & $\begin{array}{l}0 \\
(0.00)\end{array}$ & $\begin{array}{l}0 \\
(0.00)\end{array}$ & 53 \\
\hline $\begin{array}{l}\text { Over } \\
\text { Perfo }\end{array}$ & $\begin{array}{l}\text { all } \\
\text { rmance }\end{array}$ & $\begin{array}{l}239 \\
(59.31)\end{array}$ & $\begin{array}{l}131 \\
(32.51)\end{array}$ & $\begin{array}{l}17 \\
(4.22)\end{array}$ & $\begin{array}{l}15 \\
(3.72) \\
\end{array}$ & 403 \\
\hline
\end{tabular}

Note*Percentages $\%$ in bracket

Table 1 revealed that the performance of students from rural area in Business Studies Examination for 2016/2017 Academic Session in public secondary schools in Sapele Local Government Area of Delta State was satisfactory. Out of 403 students that sat for the examination, 239 representing 59.31\% had Excellent, 131 representing 32.51\% had Credit, 17 representing $4.22 \%$ had Pass, and 15 representing 3.72\% Failed.

Research Question 2: What is the performance of students from urban area in Business Studies Examination for 2016/2017 Academic Session in public secondary schools in Sapele Local Government Area of Delta State? 
Table 2. Performance of students from urban area in Business Studies Examination for 2016/2017 Academic Session in public secondary schools in Sapele Local Government Area of Delta State

\begin{tabular}{|c|c|c|c|c|c|c|}
\hline $\mathbf{S} / \mathbf{N}$ & $\begin{array}{l}\text { Name } \\
\text { Schools }\end{array}$ & $\begin{array}{lr}\text { Number } & \text { of } \\
\text { Students } & \text { with } \\
\text { Excellent } & \\
\text { Grade } & \\
\end{array}$ & $\begin{array}{l}\text { Number of } \\
\text { Students with } \\
\text { Credit Grade }\end{array}$ & $\begin{array}{l}\text { Number of } \\
\text { Students with } \\
\text { Pass Grade }\end{array}$ & $\begin{array}{l}\text { Number of } \\
\text { Students with } \\
\text { Fail Grade }\end{array}$ & $\begin{array}{l}\text { Total } \\
\text { Numbers of } \\
\text { Students }\end{array}$ \\
\hline 1. & $\begin{array}{l}\text { Orodje } \\
\text { Secondary } \\
\text { School }\end{array}$ & $\begin{array}{l}80 \\
(37.38)\end{array}$ & $\begin{array}{l}133 \\
(62.15)\end{array}$ & $\begin{array}{l}0 \\
(0.00)\end{array}$ & $\begin{array}{l}1 \\
(0.467)\end{array}$ & 214 \\
\hline 2. & $\begin{array}{l}\text { Zik Secondary } \\
\text { School }\end{array}$ & $\begin{array}{l}128 \\
(32.08)\end{array}$ & $\begin{array}{l}246 \\
(61.65)\end{array}$ & $\begin{array}{l}4 \\
(10.03)\end{array}$ & $\begin{array}{l}21 \\
(5.26)\end{array}$ & 399 \\
\hline 3. & $\begin{array}{l}\text { Eziafa } \\
\text { Secondary } \\
\text { School }\end{array}$ & $\begin{array}{l}15 \\
(12.20)\end{array}$ & $\begin{array}{l}101 \\
(82.11)\end{array}$ & $\begin{array}{l}7 \\
(5.69)\end{array}$ & $\begin{array}{l}0 \\
(0.00)\end{array}$ & 123 \\
\hline 4. & $\begin{array}{l}\text { Ethiope } \\
\text { Secondary } \\
\text { School }\end{array}$ & $\begin{array}{l}80 \\
(39.60)\end{array}$ & $\begin{array}{l}93 \\
(46.04)\end{array}$ & $\begin{array}{l}25 \\
(12.38)\end{array}$ & $\begin{array}{l}4 \\
(1.98)\end{array}$ & 202 \\
\hline 5. & $\begin{array}{l}\text { Ufuoma Mixed } \\
\text { Secondary } \\
\text { School }\end{array}$ & $\begin{array}{l}118 \\
(50.21)\end{array}$ & $\begin{array}{l}109 \\
(46.38)\end{array}$ & $\begin{array}{l}3 \\
(1.28)\end{array}$ & $\begin{array}{l}5 \\
(2.13)\end{array}$ & 235 \\
\hline 6. & $\begin{array}{l}\text { Urhiapele } \\
\text { Secondary } \\
\text { School }\end{array}$ & $\begin{array}{l}70 \\
(33.82)\end{array}$ & $\begin{array}{l}93 \\
(44.93)\end{array}$ & $\begin{array}{l}28 \\
(13.53)\end{array}$ & $\begin{array}{l}16 \\
(7.73)\end{array}$ & 207 \\
\hline 7. & $\begin{array}{l}\text { Gana Mixed } \\
\text { Secondary } \\
\text { School }\end{array}$ & $\begin{array}{l}48 \\
(28.57)\end{array}$ & $\begin{array}{l}111 \\
(66.07)\end{array}$ & $\begin{array}{l}6 \\
(3.57)\end{array}$ & $\begin{array}{l}3 \\
(1.79)\end{array}$ & 168 \\
\hline 8. & $\begin{array}{l}\text { Chude Girls } \\
\text { Model School }\end{array}$ & $\begin{array}{l}32 \\
(18.71)\end{array}$ & $\begin{array}{l}132 \\
(77.19)\end{array}$ & $\begin{array}{l}3 \\
(1.75)\end{array}$ & $\begin{array}{l}4 \\
(2.34)\end{array}$ & 171 \\
\hline 9. & $\begin{array}{l}\text { Okpe } \\
\text { Grammar } \\
\text { School }\end{array}$ & $\begin{array}{l}73 \\
(29.32)\end{array}$ & $\begin{array}{l}153 \\
(61.45)\end{array}$ & $\begin{array}{l}18 \\
(7.23)\end{array}$ & $\begin{array}{l}5 \\
(2.00)\end{array}$ & 249 \\
\hline 10. & $\begin{array}{l}\text { Okotie Eboh } \\
\text { Grammar } \\
\text { School }\end{array}$ & $\begin{array}{l}10 \\
(4.81)\end{array}$ & $\begin{array}{l}105 \\
(50.48)\end{array}$ & $\begin{array}{l}24 \\
(11.54)\end{array}$ & $\begin{array}{l}69 \\
(33.17)\end{array}$ & 208 \\
\hline $\begin{array}{l}\text { Over } \\
\text { Perfo }\end{array}$ & $\begin{array}{l}\text { all } \\
\text { rmance }\end{array}$ & $\begin{array}{l}654 \\
(30.06)\end{array}$ & $\begin{array}{l}1276 \\
(58.64)\end{array}$ & $\begin{array}{l}118 \\
(5.42)\end{array}$ & $\begin{array}{l}128 \\
(5.88)\end{array}$ & 2176 \\
\hline
\end{tabular}

Note*Percentages $\%$ in bracket

Table 2 revealed that the performance of students from urban area in Business Studies Examination for 2016/2017 Academic Session in public secondary schools in Sapele Local Government Area of Delta State was satisfactory. Out of 2176 students that sat for the examination, 654 Representing 30.06\% had Excellent, 1276 representing $58.64 \%$ had Credit, 118 representing 5.42\% had Pass, and 128 representing $5.88 \%$ Failed.

Research Question 3: What is the performance of students in Business Studies Examination for 2016/2017 Academic Session in public secondary schools in Sapele Local Government Area of Delta State taught by teachers with N.C.E.? 
Table 3. Performance of students in Business Studies Examination for 2016/2017 Academic Session in public secondary schools in Sapele Local Government Area of Delta State taught by teachers with N.C.E

\begin{tabular}{|c|c|c|c|c|c|c|}
\hline $\mathbf{S} / \mathbf{N}$ & $\begin{array}{ll}\text { Name } & \text { of } \\
\text { Schools } & \end{array}$ & $\begin{array}{lr}\text { Number } & \text { of } \\
\text { Students } & \text { with } \\
\text { Excellent } & \\
\text { Grade } & \\
\end{array}$ & $\begin{array}{l}\text { Number of } \\
\text { Students with } \\
\text { Credit Grade }\end{array}$ & $\begin{array}{l}\text { Number of } \\
\text { Students with } \\
\text { Pass Grade }\end{array}$ & $\begin{array}{l}\text { Number of } \\
\text { Students with } \\
\text { Fail Grade }\end{array}$ & $\begin{array}{l}\text { Total } \\
\text { Numbers of } \\
\text { Students }\end{array}$ \\
\hline 1. & $\begin{array}{l}\text { Orodje } \\
\text { Secondary } \\
\text { School }\end{array}$ & $\begin{array}{l}80 \\
(37.38)\end{array}$ & $\begin{array}{l}133 \\
(62.15)\end{array}$ & $\begin{array}{l}0 \\
(0.00)\end{array}$ & $\begin{array}{l}1 \\
(0.467)\end{array}$ & 214 \\
\hline 2. & $\begin{array}{l}\text { Urhiapele } \\
\text { Secondary } \\
\text { School }\end{array}$ & $\begin{array}{l}70 \\
(33.82)\end{array}$ & $\begin{array}{l}93 \\
(44.93)\end{array}$ & $\begin{array}{l}28 \\
(13.53)\end{array}$ & $\begin{array}{l}16 \\
(7.73)\end{array}$ & 207 \\
\hline 3. & $\begin{array}{l}\text { Gana Mixed } \\
\text { Secondary } \\
\text { School }\end{array}$ & $\begin{array}{l}48 \\
(28.57)\end{array}$ & $\begin{array}{l}111 \\
(66.07)\end{array}$ & $\begin{array}{l}6 \\
(3.57)\end{array}$ & $\begin{array}{l}3 \\
(1.79)\end{array}$ & 168 \\
\hline 4. & $\begin{array}{l}\text { Okotie Eboh } \\
\text { Grammar } \\
\text { School }\end{array}$ & $\begin{array}{l}10 \\
(4.81)\end{array}$ & $\begin{array}{l}105 \\
(50.48)\end{array}$ & $\begin{array}{l}24 \\
(11.54)\end{array}$ & $\begin{array}{l}69 \\
(33.17)\end{array}$ & 208 \\
\hline $\begin{array}{l}\text { Over } \\
\text { Perf }\end{array}$ & $\begin{array}{l}\text { all } \\
\text { rmance }\end{array}$ & $\begin{array}{l}208 \\
(26.10)\end{array}$ & $\begin{array}{l}442 \\
(55.46)\end{array}$ & $\begin{array}{l}58 \\
(7.28)\end{array}$ & $\begin{array}{l}89 \\
(11.17)\end{array}$ & 797 \\
\hline
\end{tabular}

Note*Percentages $\%$ in bracket

Table 3 revealed that the performance of students in Business Studies Examination for 2016/2017 Academic Session in public secondary schools in Sapele Local Government Area of Delta State taught by teachers with N.C.E. was satisfactory. Out of 797 students that sat for the examination, 208 Representing $26.10 \%$ had Excellent, 442 representing 55.46\% had Credit, 58 representing $7.28 \%$ had Pass, and 89 representing $11.17 \%$ Failed.

Research Question 4: What is the performance of students in Business Studies Examination for 2016/2017 Academic Session in public secondary schools in Sapele Local Government Area of Delta State taught by teachers with B.Sc Ed?

Table 4. The performance of students in Business Studies Examination for 2016/2017 Academic Session in public secondary schools in Sapele Local Government Area of Delta State taught by teachers with B.Sc Ed

\begin{tabular}{|c|c|c|c|c|c|c|}
\hline $\mathbf{S} / \mathbf{N}$ & $\begin{array}{l}\text { Name } \\
\text { Schools }\end{array}$ & $\begin{array}{lr}\text { Number of } \\
\text { Students with } \\
\text { Excellent Grade }\end{array}$ & $\begin{array}{l}\text { Number of } \\
\text { Students with } \\
\text { Credit Grade } \\
\end{array}$ & $\begin{array}{l}\text { Number of } \\
\text { Students with } \\
\text { Pass Grade }\end{array}$ & $\begin{array}{l}\text { Number of } \\
\text { Students with } \\
\text { Fail Grade }\end{array}$ & $\begin{array}{l}\text { Total } \\
\text { Numbers of } \\
\text { Students } \\
\end{array}$ \\
\hline 1. & $\begin{array}{l}\text { Zik } \\
\text { Secondary } \\
\text { School }\end{array}$ & $\begin{array}{l}128 \\
(32.08)\end{array}$ & $\begin{array}{l}246 \\
(61.65)\end{array}$ & $\begin{array}{l}4 \\
(10.03)\end{array}$ & $\begin{array}{l}21 \\
(5.26)\end{array}$ & 399 \\
\hline 2. & $\begin{array}{l}\text { Ethiope } \\
\text { Secondary } \\
\text { School }\end{array}$ & $\begin{array}{l}80 \\
(39.60)\end{array}$ & $\begin{array}{l}93 \\
(46.04)\end{array}$ & $\begin{array}{l}25 \\
(12.38)\end{array}$ & $\begin{array}{l}4 \\
(1.98)\end{array}$ & 202 \\
\hline 3. & $\begin{array}{l}\text { Chude Girls } \\
\text { Model } \\
\text { School }\end{array}$ & $\begin{array}{l}32 \\
(18.71)\end{array}$ & $\begin{array}{l}132 \\
(77.19)\end{array}$ & $\begin{array}{l}3 \\
(1.75)\end{array}$ & $\begin{array}{l}4 \\
(2.34)\end{array}$ & 171 \\
\hline 4. & $\begin{array}{l}\text { Elume } \\
\text { Grammar } \\
\text { School }\end{array}$ & $\begin{array}{l}34 \\
(64.15)\end{array}$ & $\begin{array}{l}19 \\
(35.85)\end{array}$ & $\begin{array}{l}0 \\
(0.00)\end{array}$ & $\begin{array}{l}0 \\
(0.00)\end{array}$ & 53 \\
\hline $\begin{array}{l}\text { Ove } \\
\text { Perf }\end{array}$ & $\begin{array}{l}\text { all } \\
\text { rmance }\end{array}$ & $\begin{array}{l}274 \\
(33.21)\end{array}$ & $\begin{array}{l}490 \\
(59.40)\end{array}$ & $\begin{array}{l}32 \\
(3.88)\end{array}$ & $\begin{array}{l}29 \\
(3.52)\end{array}$ & 825 \\
\hline
\end{tabular}

Note* Percentages \% in bracket

Table 4 revealed that the performance of students in Business Studies Examination for 2016/2017 Academic Session in public secondary schools in Sapele Local Government Area of Delta State taught by teachers with 
B.Sc Ed was satisfactory. Out of 825 students that sat for the examination, 274 Representing $33.21 \%$ had Excellent, 490 representing 59.40\% had Credit, 32 representing 3.88\% had Pass, and 29 representing 3.52\% Failed.

\section{Discussion of Results}

The results will be discussed based on research questions:

The results revealed that the performance of students from rural and urban area in Business Studies Examination for 2016/2017 Academic Session in public secondary schools in Sapele Local Government Area of Delta State was satisfactory. The results show that location does not have significant effects on students' performance. These findings is in line with Reeves and Bylund (2005) who believed that school location whether urban or rural does not affect academic achievement of students. On a contrary, Zappala (2002) in Idialu (2013) found out that location significantly influenced students' academic performance and there was significance difference in the performance of students from urban and rural schools. As well, Idialu (2013) citing Onyeagu (2000) reported that, there is no locational influence on the performance of students.

Also, the results revealed that the performance of students in Business Studies Examination for 2016/2017 Academic Session in public secondary schools in Sapele Local Government Area of Delta State taught by teachers with N.C.E and B.Sc Ed was satisfactory. The findings revealed that qualification of teacher has significant effects on students' performance. This finding is in line with Okoye, Momoh, Aigbomian, and Okecha (2008) study which revealed that teacher quality had positive significant relationship with performance in secondary schools in Delta State. Also, Akpo (2012) reported that teacher educational qualifications have significant relationship with students' academic performance. However, Duze (2012) reported contrary view that teachers' qualification has no significant relationship to students' academic performance in public junior secondary schools (JSS) in Delta Central Senatorial District of Delta State.

\section{Conclusion and Recommendations}

Based on the findings of this study, it was concluded that school location does not have significant effects on students' performance in Business Studies examination in secondary schools in Delta State. As well, teachers' qualification has significant effects on students' performance in Business Studies examination in secondary schools in Delta State. This implies that students' performance in Business Studies examination in schools that have highly qualified teachers performed significantly better than their counterparts who were taught by teacher with low qualification. Hence, the following recommendations were made based on the findings from the study:

i. Delta State Ministry of Basic and Secondary Education should employ qualified teachers to teach Business Studies in secondary schools in Delta State.

ii. Delta State Ministry of Basic and Secondary Education should introduce Business Studies teachers development scheme to enable teachers with lower qualification upgrade their knowledge.

iii. Delta State Ministry of Basic and Secondary Education should evenly distribute teachers with respect to their qualification and school location.

iv. Delta State Ministry of Basic and Secondary Education should establish more secondary schools in rural areas.

\section{References}

Afe, J. O. (2001). Reflections on becoming a teacher and the challenges of teacher education. Inaugural Lecture Series 64. Benin City: University of Benin, Nigeria.

Ajao, W. (2001). Cadbury is determined to move education forward. Vanguard, 16.

Akinfe, E.. Olofinniyi, O. E., \& Fashiku, C. O. (2012). Teachers' quality as correlates of students' academic performance in Biology in senior secondary schools in Ondo State, Nigeria. Online Journal of Education Research, 1(6).

Akiri, A. A., \& Ugborugbo, N. M. (2009). Teachers' effectiveness and students' academic performance in public secondary schools in Delta State Nigeria. Stud Home Comm Sci, 3(2), 107-113. https://doi.org/10.1080/09737189.2009.11885284

Akpo, S. E. (2012). The impact of teacher-related variables on students' junior secondary certificate mathematics results in Namibia. Ph. D Thesis, University of South Africa, School of Education.

Duze, C. O. (2012). Principals' perception of educational inputs and students' academic performance in junior secondary schools in Delta State of Nigeria. African Research Review, 6(1), 360-379. https://doi.org/10.4314/afrrev.v6i1.29 
Ewetan, T. O., \& Ewetan, O. O. (2015). Teachers' teaching experience and academic performance in Mathematics and English Language in public secondary schools in Ogun State Nigeria. International Journal of Humanities Social Sciences and Education (IJHSSE), 2(2), 123-134.

Federal Republic of Nigeria (FRN, 2004). National policy on education. Lagos: NERDC Press.

Idialu, J. O. (2013). Influence of gender, school location and students' attitude on academic achievement in Basic Technology in Delta State. PhD Thesis Submitted to the Department of Vocational Teacher Education, University of Nigeria, Nsukka.

Nelson, C. G. (2004). The diversity challenge in urban and rural education. English Journal, 93(6), 22-23. https://doi.org/10.2307/4128887

Nwachukwu, M. N. (2004). Influence of home school environment and teaching strategies in secondary school achievement in Ondo State (Unpublished M.Ed thesis), University of Ibadan.

Nwogu, U. F. (2011). Strategies considered effective by Business Educators for improving the teaching of Business subjects at the senior secondary school level. M.Sc Thesis, Department of Vocational Education, Nnamdi Azikiwe University, Awka.

Ofoegbu, F. I. (2004). Teacher motivation: a factor for classroom effectiveness and school improvement in Nigeria. Gale Group. Retrieved from http://www.findArticles.com

Okolocha, C. C., \& Onyeneke, E. N. (2013). Secondary school principals' perception of Business Studies teachers' teaching effectiveness in Anambra State Nigeria. Journal of Education and Practice, 4(2), 171-179.

Okoye, N. S., Momoh, S. O., Aigbomian, D. O., \& Okecha, R. E. (2008). Teachers' quality instructional strategies and students performance in secondary school science. Journal of Instructional Psychology, $35(2)$.

Reeves, E. B., \& Bylund, R. A. (2005). Are rural Schools inferior to urban schools? A multilevel analysis of school accountability trends in Kentucky. Rural Sociology, 70, 360-386. https://doi.org/10.1526/0036011054831215

Udoukpong, B. E., Emah, I. E., \& Umoren, S. E. (2012). Business Studies academic performance differences of secondary school juniors in Akwa Ibom State of Nigeria. International Education Studies, 5(2), 35-43. https://doi.org/10.5539/ies.v5n2p35

Zailani, A. (2015). Failure associated with teaching and learning of Business Studies in Public Secondary Schools in Yola North L.G.A. Adamawa. IOSR Journal of Business and Management, 17(3), 38-44.

\section{Copyrights}

Copyright for this article is retained by the author(s), with first publication rights granted to the journal.

This is an open-access article distributed under the terms and conditions of the Creative Commons Attribution license (http://creativecommons.org/licenses/by/4.0/). 